\title{
Osteoblasts stimulate the osteogenic and metastatic progression of castration-resistant prostate cancer in a novel model for in vitro and in vivo studies
}

\author{
Malin Hagberg Thulin • Karin Jennbacken • \\ Jan-Erik Damber · Karin Welén
}

Received: 23 April 2013/Accepted: 14 November 2013/Published online: 1 December 2013

(C) The Author(s) 2013. This article is published with open access at Springerlink.com

\begin{abstract}
Castration-resistant prostate cancer (CRPC) is strongly associated with sclerotic bone metastases and poor prognosis. Models that mimic human CRPC are needed to identify the mechanisms for prostate cancer (PC) growth in bone and to develop new therapeutic strategies. We characterize a new model, LNCaP-19, and investigate the interaction between tumor cells and osteoblasts in the sclerotic tumor response of CRPC. Osteogenic profiling of PC cell lines (LNCaP-19, LNCaP, C4-2B 4 , and PC-3) was performed by gene expression arrays and mineral staining. Conditioned medium from MC3T3-E1 was used for osteoblast stimulation of CRPC cells. The capacity of LNCaP-19 cells to induce sclerotic lesions was assessed in intratibial xenografts and verified by serum markers, histological analysis and bone mineral density (BMD) measurements. The CRPC cell line LNCaP-19 expresses a pronounced osteogenic profile compared to its parental androgen-dependent cell line LNCaP. Osteoblast-derived factors further increase the expression of genes known to enhance metastatic progression of PC. LNCaP-19 forms sclerotic tumors in tibia of castrated mice as evident by increased total BMD $(P<0.01)$. There was a strong correlation between serum osteocalcin and BMD (total: $R^{2} 0.811, P<0.01$, trabecular: $R^{2} 0.673, P<0.05$ ). For the first time we demonstrate that a CRPC cell line generated in vitro has osteogenic capacity and that osteomimicry can be an inherent feature of these cells. Osteoblast-derived factors further promote the osteogenic and metastatic phenotype in CRPC cells. Altogether, our model demonstrates
\end{abstract}

\footnotetext{
M. Hagberg Thulin $(\bowtie) \cdot$ K. Jennbacken · J.-E. Damber .

K. Welén

Department of Urology, Sahlgrenska Cancer Center, Institute of

Clinical Sciences, Sahlgrenska Academy at the University of

Gothenburg, Box 425, 40530 Göteborg, Sweden

e-mail: malin.hagberg@urology.gu.se
}

that both tumor cells and osteoblasts are mediators of the bone forming process of CRPC.

Keywords Castration-resistant prostate cancer . Bone metastasis · Osteoblasts · Osteomimicry

\section{Background}

Today there are limited therapeutic alternatives for patients with advanced prostate cancer (PC), and androgen deprivation therapy (ADT) is the primary option. ADT is initially highly effective in suppressing tumor growth. However, it leads to increased bone degradation resulting in the release of growth factors from the bone matrix, many of which can stimulate prostate cancer (PC) cell attraction and tumor growth in bone [1-3]. The outcome for most patients with ADT-treated advanced PC is relapse of castration-resistant disease (CRPC) with bone metastasis, for which no curative treatment exists.

Bone metastases behave differently depending on their tumor origin. Metastases from breast and lung cancers are primarily osteolytic, inducing bone degradation $[2,4,5]$, while bone metastases from PC form sclerotic lesions characterized by excessive deposition of unstructured new woven bone [3, 6-8]. These observations suggest that osteoblasts play a central role in the metastatic process in CRPC in the bone compartment.

Skeletal metastasis is the consequence of the bidirectional interplay between tumor cells and bone cells. Metastatic PC cells produce a variety of bone-stimulating factors including prostate specific antigen (PSA), endothelin-1, bone morphogenetic proteins (BMPs) and insulinlike growth factor 1 (IGF-1), that have direct or indirect effects on bone formation [9-11]. Moreover, osteoblasts 
secrete several factors including IGF-1, TGF- $\beta$ and BMPs, which that facilitate the growth and survival of PC cells in the bone $[12,13]$. These soluble factors potentiate a paracrine crosstalk between PC cells and bone cells, commonly termed "the vicious cycle" $[2,14]$ and play an important role in the formation of osteoblastic tumors in CRPC.

Tumor cells that preferentially metastasize to bone acquire features normally expressed by bone cells, particular to the osteoblastic phenotype, an adaptation referred to as osteomimicry [15-17]. The acquisition of osteogenic properties by tumor cells may enhance their capacity to communicate with their host organ and hence promote their capacity to survive and proliferate in the bone environment. It is not clear when the osteomimetic adaptation occurs. Some tumor cells at the primary site may already express a bone-like phenotype which would facilitate their metastasis to bone. Alternatively, seeding in the bone is stimulated by local factors converting the tumor cells to an osteomimetic stage (reviewed in [17]). The development of phenotypic bone changes in PC cells accompanying the development of castration resistance and communication with the bone environment is not well understood.

The understanding of the bone metastatic disease, and hence, the development of efficient and specific treatments is limited due to the difficulty of obtaining samples from bone metastases from patients. Therefore, models that mimic the human disease are critical for elucidation of alterations in both tumors and bone cells and for evaluation of new therapeutics. Today, few models exist to study the osteoblastic function of CRPC, for example LuCAP-23.1 and MDA-PCa $2 \mathrm{a}$ and $2 \mathrm{~b}$ form osteoblastic lesions while C4-2B, IGR-CaP1 and PCSD1 give mixed osteolytic/ osteoblastic lesions [18-22].

The overall aim with this study was to characterize a novel model, LNCaP-19, for studies of the osteoblastic process in metastases of CRPC under castrated conditions reflecting the clinical situation. LNCaP-19 was established in our laboratory as an in vitro derived castration-resistant subclone of LNCaP [23]. It has an increased angiogenic and invasive potential compared to its parental cell line $[24,25]$. Compared to $\mathrm{LNCaP}$, it also has metastatic potential $[26,27]$.

We here show that LNCaP-19 is suitable for studies of the osteoblastic function of CRPC, in a bidirectional system both in vitro and in vivo. We demonstrate that osteomimicry can be an inherent feature of PC cells, which is further potentiated by the acquisition of castration-resistance. We also show that osteoblasts trigger a more pronounced osteogenic and aggressive phenotype of the CRPC cells and initiate a cross-talk between tumor- and bone cells. Importantly, this study demonstrates that both tumor cells and osteoblasts are potential mediators of bone formation.

\section{Results}

LNCaP-19 has the capacity to mineralize extracellular bone matrix

It is known that bone metastases are a result of the communication between bone and cancer cells and that PC cells acquire bone-like properties during disease progression. Therefore, in the present study, we investigated the ability of the LNCaP-19 cells to mineralize extracellular bone matrix. After 21 days of culture in steroid-depleted medium, both promineralization medium (PM) and osteoblastconditioned medium (OCM) induced mineralization in LNCaP-19 compared to control medium ( $\alpha$ MEM) or fibroblast-conditioned medium (FCM) (Fig. 1a). A strong staining of alkaline phosphatase (Alp) activity was detected in LNCaP-19 cells stimulated with PM, compared to cells cultured in control medium or OCM. FCM did not stimulate Alp activity (Fig. 1b). In agreement with a previous study [28], LNCaP did not mineralize when cultured in PM medium or in OCM (data not shown). Functional studies of the osteoblastic influence on LNCaP-19 cells demonstrated clear morphological changes in OCM stimulated cells compared to control cells (Fig. 1c). As shown in Fig. 1d, proliferation of OCM-stimulated LNCaP-19 cells was significantly increased $(P<0.05)$ compared to control cells treated with L19CM and FCM. This OCM-specific stimulation was only seen in LNCaP-19 since both OCM and FCM stimulated LNCaP proliferation 1.8 times compared to LNCaP-CM (data not shown).

LNCaP-19 cells display a pronounced osteogenic gene expression profile

As the castration-resistant LNCaP-19 was able to mineralize, an osteogenesis gene signature array was used to identify the underlying gene program responsible for its osteomimetic properties. The osteogenic phenotype was compared between four different PC cell lines, LNCaP-19, mixed osteoblastic/osteolytic LNCaP (androgen-dependent) and $\mathrm{C}_{4}-2 \mathrm{~B}_{4}$ (castration-resistant) and the osteolytic castration-resistant cell line PC-3. All four cell lines expressed detectable levels of the majority of the genes included in the osteogenesis array, such as the transcription factor of the osteoblastic lineage msh homeobox 2 (MSX2) as well as bone morphogenetic protein $(B M P)-1,-4$ and -6 , SMADs and osteonectin (Osn, SPARC) (Table 1). The key transcription factor of the osteoblastic lineage runt-related transcription factor $2(R U N X 2)$ and alkaline phosphatase $(A L P L)$ were expressed in LNCaP-19, LNCaP and PC-3 but absent in $\mathrm{C}_{4}-2 \mathrm{~B}_{4}$.

LNCaP-19 and C4-2B 4 are both derived from $\mathrm{LNCaP}$ and display osteogenic phenotypes. Comparing the 
Fig. 1 Osteoblasts induce LNCaP-19 mineralization and proliferation. LNCaP-19 cells were seeded in 6-well plates $\left(1 \times 10^{5}\right.$ cells/well $)$ and in 12 -well plates $\left(4 \times 10^{4}\right.$ cells/well $)$ for von Kossa staining respectively alkaline phosphatase (ALP) staining and cultured with fibroblastconditioned medium (FCM), control medium ( $\alpha$ MEM), osteoblast-conditioned (OCM), or promineralization medium (PM; $\alpha \mathrm{MEM}$ supplemented with ascorbic acid $(50 \mu \mathrm{g} / \mathrm{ml})$ and $\beta$ glycerophosphate) (10 mM) under steroid deprived conditions (10\% FBS-DCC). a Mineralization of LNCaP-19, visualized after 21 days by von Kossa staining. b Staining of ALP activity after 21 days in culture. c Morphological changes in LNCaP-19 after $48 \mathrm{~h}$ in culture with OCM, FCM or control medium (L19CM) visualized with phase contrast light microscopy, magnification $\times 200$. d Proliferation of LNCaP-19 cells. For proliferation, $\mathrm{LNCaP}-19$ cells were seeded in 96-well plates $\left(5 \times 10^{3}\right.$ cells/well $)$ and stimulated with control medium (L19 CM), OCM or FCM. All media was supplemented with $1 \%$ FBS-DCC. Proliferation of LNCaP-19 was measured by BrdU incorporation after 48 and 96 h. Bars represent mean \pm SEM of three independent experiments. $* P<0.05$ versus control
A

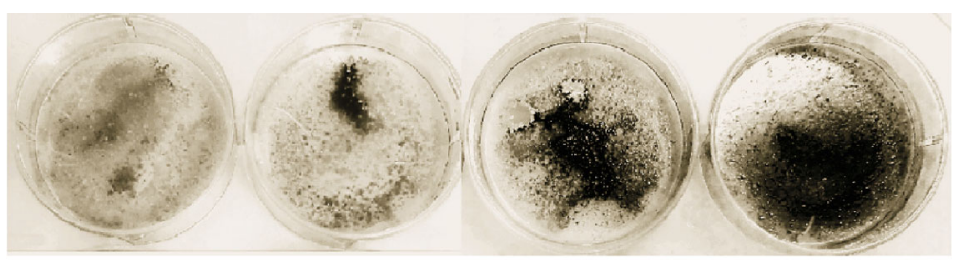

B

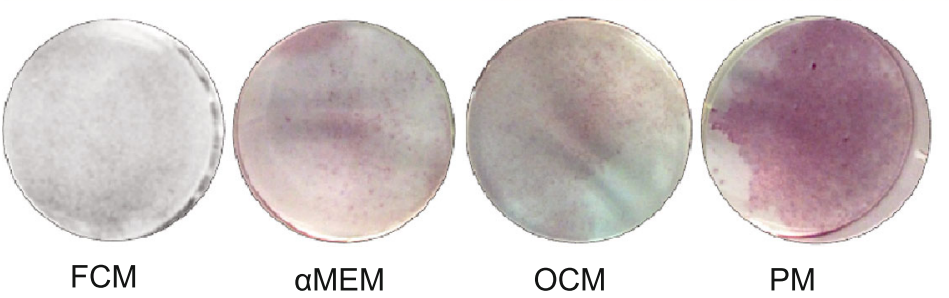

C

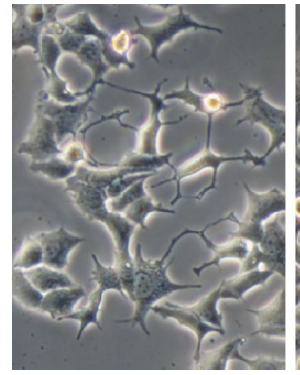

L19 CM
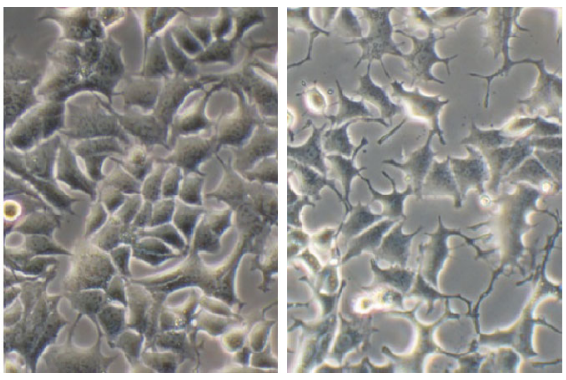

OCM

FCM

D

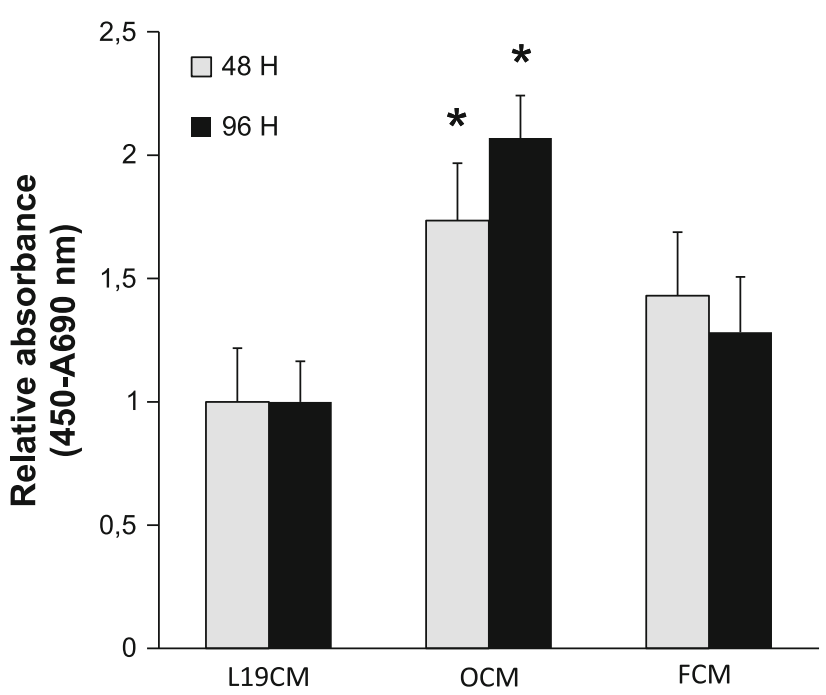

aggressive PC and mineralization process of enamel, which was absent in LNCaP.

A distinct pattern of genes involved in osteoclastogenesis and inhibition of bone formation, including colony stimulating factor 2 (CSF2), twist homolog 2 (TWIST2) and $B M P 3$, were exclusively expressed in PC-3.

Osteoblasts stimulate changes in the gene expression profile of prostate cancer cells

The osteogenesis gene signature array was further used to detect differently expressed genes in LNCaP-19, LNCaP, 
Table 1 Basal expression of osteogenesis- associated genes in prostate cancer cell lines

\begin{tabular}{|c|c|c|c|c|c|}
\hline \multirow[t]{2}{*}{ Gene symbol } & \multicolumn{4}{|c|}{ Expression levels } & \multirow[t]{2}{*}{ Gene description } \\
\hline & LNCaP-19 & LNCaP & $\mathrm{C} 4-2 \mathrm{~B}_{4}$ & PC-3 & \\
\hline$A H S G$ & ND & ND & $*$ & ND & Alpha-2-HS-glycoprotein \\
\hline$A R S E$ & ND & ND & ND & $* *$ & Arylsulfatase E (chondrodysplasia punctata 1) \\
\hline$A L P L$ & $* *$ & $*$ & ND & $*$ & Alkaline phosphatase, liver/bone/kidney \\
\hline$B G L A P$ & ND & $*$ & $*$ & $*$ & Bone gamma-carboxyglutamate (gla) protein \\
\hline$B M P 1$ & $* * *$ & $* *$ & $* *$ & $* *$ & Bone morphogenetic protein 1 \\
\hline$B M P 2$ & $* *$ & ND & ND & $*$ & Bone morphogenetic protein 2 \\
\hline$B M P 3$ & ND & ND & ND & $* * *$ & Bone morphogenetic protein 3 \\
\hline BMP4 & $* *$ & $* *$ & $* *$ & $* * *$ & Bone morphogenetic protein 4 \\
\hline BMP5 & ND & $*$ & ND & $*$ & Bone morphogenetic protein 5 \\
\hline BMP6 & $* *$ & $* *$ & $* *$ & ** & Bone morphogenetic protein 6 \\
\hline$B M P 7$ & $* *$ & $*$ & $* * *$ & ND & Bone morphogenetic protein 7 \\
\hline$B M P R 1 A$ & $* * * *$ & $* * *$ & $* * *$ & $* * *$ & Bone morphogenetic protein receptor, type IA \\
\hline $\mathrm{CDH} 11$ & $*$ & ND & ND & $* * * *$ & Cadherin 11 , type 2 , OB-cadherin \\
\hline COL1A1 & $* *$ & ND & ND & $* * *$ & Collagen, type I, alpha 1 \\
\hline COL3A1 & $* *$ & $* *$ & $* *$ & $* *$ & Collagen, type III, alpha 1 \\
\hline COLAA3 & ND & ND & $*$ & ND & Collagen, type IV, alpha 3 \\
\hline COL $4 A 4$ & ND & ND & $*$ & ND & Collagen, type IV, alpha 4 \\
\hline COLAA5 & $* * *$ & $* * *$ & $* * *$ & $* * *$ & Collagen, type IV, alpha 5 \\
\hline COL5A1 & $* *$ & $* *$ & $*$ & $* * *$ & Collagen, type $\mathrm{V}$, alpha 1 \\
\hline COL7A1 & $* * * *$ & $*$ & $* *$ & $* *$ & Collagen, type VII, alpha 1 \\
\hline COL9A2 & ND & $* *$ & $* *$ & $*$ & Collagen, type IX, alpha 2 \\
\hline COL12A1 & $* * * *$ & $* *$ & $* * *$ & $* * * *$ & Collagen, type XII, alpha 1 \\
\hline COL15A1 & ND & ND & ND & $*$ & Collagen, type XV alpha 1 \\
\hline COL16A1 & $* * *$ & $*$ & $* *$ & ND & Collagen, type XVI, alpha 1 \\
\hline COL17A1 & ND & $* *$ & $*$ & $* *$ & Collagen, type XVII, alpha 1 \\
\hline COL18A1 & ** & $* *$ & ** & $* * *$ & Collagen, type XVIII, alpha 1 \\
\hline CSF2 & ND & ND & ND & $*$ & Colony stimulating factor 2 \\
\hline CSF3 & ND & ND & ND & $* *$ & Colony stimulating factor 3 \\
\hline COMP & $* *$ & $*$ & $* *$ & $*$ & Cartilage oligomeric matrix protein \\
\hline$D S P P$ & $*$ & ND & $*$ & ND & Dentin sialophosphoprotein \\
\hline$E G F$ & $* * * *$ & $* * *$ & $* *$ & $* *$ & Epidermal growth factor \\
\hline$E G F R$ & $* * * *$ & $* * *$ & $* * *$ & $* * * *$ & Epidermal growth factor receptor \\
\hline ENAM & ND & $*$ & ND & $*$ & Enamelin \\
\hline$F G F 1$ & ND & $*$ & ND & $* *$ & Fibroblast growth factor 1 (acidic) \\
\hline$F G F 2$ & ND & $*$ & ND & $* * *$ & Fibroblast growth factor 2 (basic) \\
\hline FGFR1 & $* * *$ & $* * *$ & $* * *$ & $* * *$ & Fibroblast growth factor receptor 1 \\
\hline$F G F R 2$ & $* * * *$ & $* *$ & $* *$ & $*$ & Fibroblast growth factor receptor 2 \\
\hline$F G F R 3$ & ND & $*$ & $*$ & ND & Fibroblast growth factor receptor 3 \\
\hline$I G F 1$ & ND & $* *$ & $* *$ & ND & Insulin-like growth factor 1 \\
\hline$I G F 1 R$ & $* * *$ & $* * *$ & $* * *$ & $* * * *$ & Insulin-like growth factor 1 receptor \\
\hline$I G F 2$ & $* * *$ & $* *$ & $* *$ & $* * *$ & Insulin-like growth factor 2 \\
\hline$M G P$ & $* *$ & $*$ & $* * *$ & $*$ & Matrix Gla protein \\
\hline MINPP1 & $* * * *$ & $* * *$ & $* * *$ & $* * *$ & Multiple inositol polyphosph. hist. phosphatase, 1 \\
\hline$M M P 2$ & $* *$ & ND & ND & * & Matrix metallopeptidase 2 \\
\hline$M M P 13$ & $* *$ & $* *$ & $* *$ & $* * *$ & Matrix metallopeptidase 13 (collagenase 3) \\
\hline$M S X 1$ & $* *$ & $* *$ & $*$ & $*$ & Msh homeobox 1 \\
\hline$M S X 2$ & $* *$ & $* *$ & $* * *$ & $* *$ & Msh homeobox 2 \\
\hline
\end{tabular}


Table 1 continued

\begin{tabular}{|c|c|c|c|c|c|}
\hline \multirow[t]{2}{*}{ Gene symbol } & \multicolumn{4}{|c|}{ Expression levels } & \multirow[t]{2}{*}{ Gene description } \\
\hline & LNCaP-19 & $\mathrm{LNCaP}$ & $\mathrm{C} 4-2 \mathrm{~B}_{4}$ & PC-3 & \\
\hline$P D G F A$ & $* * * *$ & $* * *$ & $* * *$ & $* * *$ & Platelet-derived growth factor alpha polypeptide \\
\hline PHEX & $* *$ & $*$ & $* *$ & $* * *$ & Phosph regulating endopeptidase homol. X-linked \\
\hline$R U N X 2$ & $* *$ & $*$ & ND & $* * *$ & Runt-related transcription factor 2 \\
\hline SMAD1 & $* * * *$ & $* * *$ & $* * *$ & $* * *$ & SMAD family member 1 \\
\hline SMAD2 & $* * * *$ & $* * *$ & $* * *$ & $* * * *$ & SMAD family member 2 \\
\hline SMAD3 & $* * *$ & $* * *$ & $* *$ & $* * * *$ & SMAD family member 3 \\
\hline SMAD4 & $* * * *$ & $* * *$ & $* * * *$ & $* * * *$ & SMAD family member 4 \\
\hline SMAD5 & $* * * *$ & $* * * *$ & $* * * *$ & $* * * *$ & SMAD family member 5 \\
\hline SMAD6 & $* * *$ & $*$ & $* * *$ & $* * *$ & SMAD family member 6 \\
\hline SMAD7 & $* * * *$ & $* * *$ & $* * *$ & $* *$ & SMAD family member 7 \\
\hline$S M A D 9$ & $* * * *$ & $* * *$ & $* * *$ & $* * *$ & SMAD family member 9 \\
\hline SOX9 & $* * *$ & $* * *$ & $* * *$ & $* * * *$ & SRY (sex determining region Y)-box 9 \\
\hline$S P A R C$ & $* *$ & $*$ & $*$ & $* * * *$ & Secreted protein acidic, cysteine-rich (osteonectin) \\
\hline$S P P 1$ & $* * *$ & ND & ND & $*$ & Secreted phosphoprotein 1 (osteopontin) \\
\hline TFIP11 & $* * * *$ & $* * *$ & $* * *$ & $* * *$ & Tuftelin interacting protein 11 \\
\hline$T G F B 1$ & $* * *$ & $* *$ & $* *$ & $* * * *$ & Transforming growth factor, beta 1 \\
\hline$T G F B 2$ & ND & $* *$ & $* *$ & $* * *$ & Transforming growth factor, beta 2 \\
\hline TGFB3 & $* * *$ & $*$ & $* *$ & $* * *$ & Transforming growth factor, beta 3 \\
\hline TGFBRI & $* * * *$ & $* * *$ & $* * *$ & $* * *$ & Transforming growth factor, beta receptor 1 \\
\hline TGFBR2 & $* *$ & $* *$ & $* *$ & $* * * *$ & Transforming growth factor, beta receptor II \\
\hline TUFT1 & $* * * *$ & $* * *$ & $* * *$ & $* * *$ & Tuftelin 1 \\
\hline TWIST1 & $* * *$ & $* *$ & ND & $* *$ & Twist homolog 1 (Drosophila) \\
\hline TWIST2 & ND & ND & ND & * & Twist homolog 2 (Drosophila) \\
\hline$V D R$ & $* * *$ & $* * *$ & $* * *$ & $* * *$ & Vitamin D (1,25-dihydroxyvitamin D3) receptor \\
\hline$V E G F A$ & $* * * *$ & $* * *$ & $* * *$ & $* * *$ & Vascular endothelial growth factor A \\
\hline$V E G F B$ & $* * * *$ & $* * *$ & $* * *$ & $* * *$ & Vascular endothelial growth factor B \\
\hline VEGFC & ND & ND & ND & $* * *$ & Vascular endothelial growth factor $\mathrm{C}$ \\
\hline
\end{tabular}

Gene expression in LNCaP-19, LNCaP, C4-2B4 and PC-3 cells after 48 h cultured under steroid deprived basal conditions analyzed by a gene signature array comprising 96 genes associated with osteogenesis. GUSB was used as endogenous control. The expression is graded based on $\Delta C t$-values $\left(C t\right.$-gene $-C t$-GUSB $\left._{\text {- }}\right)$. **** $\Delta C t<1 ; * * * \Delta C t<5 ; * * \Delta C t<10 ; * \Delta C t<15 . \Delta C t$ represents the mean value of three biological replicates. Non detected (ND) genes in LNCaP-19, LNCaP, C4-2B 4 , and PC-3 were, AMBN, AMELY, CALCR, CASR, COL14A1, COL19A1, COL1A2, DMP1, FGF3, FLT1, GDF10, IBSP, MMP8, SOST, STATH

C4-2 $\mathrm{B}_{4}$ and PC-3 cells after OCM-stimulation. Genes expressed at significantly different levels are presented in Table 2. Upon OCM stimulation, elevated expression of several genes associated with osteoblast function and tumor aggressiveness was demonstrated in both LNCaP-19 and LNCaP, including DSPP and RUNX2. A more pronounced osteogenic profile was observed in OCM stimulated LNCaP-19 cells compared to LNCaP, with increased expression of $\mathrm{CDH} 1 \mathrm{l}$ and matrix metalloproteinase-2 (MMP2) both associated with osteoblast communication and bone-tropic metastasis of PC. These genes were undetected in LNCaP. Furthermore, two genes were downregulated in LNCaP-19, collagen 16a1 (COL16A1) and matrix metalloproteinase-13 (MMP13; $\sim 2$ fold). Importantly, these genes are associated with chondrocytogenesis and osteoclastogenesis, respectively. The expression of the bone matrix proteins Osn and Opn was shown to be upregulated OCM-stimulated LNCaP cells, while their expression levels were unchanged in LNCaP-19. C4-2B 4 was less responsive to OCM stimulation. However, $\mathrm{C} 4-2 \mathrm{~B}_{4}$, which lacks detectable basal expression of $R U N X 2$, responded to OCM with induction of this transcription factor. Unique for $C 4-2 B_{4}$ was the induction of fibroblast growth factor 1 and -2 after OCM stimulation.

None of the osteoblast-associated genes were changed in the osteolytic PC-3 cells in response to OCM stimulation. In contrast, PC-3 cells displayed an increased expression level of $B M P 2$, an inhibitor of bone formation. In addition, significant downregulation of the Bmp2 antagonist $M G P$ 
Table 2 Differently expressed genes in prostate cancer cell lines after osteoblast stimulation

\begin{tabular}{|c|c|c|c|c|c|}
\hline \multirow[t]{2}{*}{ Gene symbol } & \multicolumn{4}{|l|}{ Fold change } & \multirow[t]{2}{*}{ Gene description } \\
\hline & LNCaP-19 & $\mathrm{LNCaP}$ & $\mathrm{C} 4-2 \mathrm{~B}_{4}$ & PC-3 & \\
\hline$D S P P$ & $4.54 *$ & + & $=$ & $=$ & Dentin sialophosphoprotein \\
\hline RUNX2 & $3.82 *$ & 3.13 & + & $=$ & Runt-related transcription factor 2 \\
\hline $\mathrm{CDH11}$ & $3.59 *$ & ND & ND & $=$ & Cadherin 11 , type 2 , osteoblast-cadherin \\
\hline COL3A1 & 2.62 & $=$ & $=$ & $=$ & Collagen, type III, alpha 1 \\
\hline$M M P 2$ & $2.43 *$ & ND & $=$ & $=$ & Matrix metallopeptidase 2 \\
\hline COL17A1 & + & $=$ & $=$ & $=$ & Collagen, type XVII, alpha 1 \\
\hline$M M P 13$ & $-2.22 *$ & ND & $=$ & $=$ & Matrix metallopeptidase 13 \\
\hline COL16A1 & -3.2 & $=$ & $=$ & $=$ & Collagen, type XVI, alpha 1 \\
\hline$S P A R C$ & $=$ & $3.47 *$ & ND & $=$ & Osteonectin \\
\hline$S P P 1$ & $=$ & + & ND & $=$ & Osteopontin \\
\hline$F G F 1$ & $=$ & $=$ & + & $=$ & Fibroblast growth factor 1 \\
\hline$F G F 2$ & $=$ & $=$ & + & $=$ & Fibroblast growth factor 2 \\
\hline$B M P 2$ & $=$ & $=$ & $=$ & $6.62 *$ & Bone morphogenetic protein 2 \\
\hline COL1A2 & $=$ & $=$ & $=$ & + & Collagen, type I, alpha 2 \\
\hline$M G P$ & $=$ & $=$ & $=$ & -2.00 & Matrix Gla protein \\
\hline$A L P L$ & $=$ & $=$ & $=$ & -2.08 & Alkaline phosphatase, liver/bone/kidney \\
\hline
\end{tabular}

mRNA expression in LNCaP-19, LNCaP, C4-2 $\mathrm{B}_{4}$ and PC-3 was analyzed by an osteogenesis gene signature array after $48 \mathrm{~h}$ of OCM (osteoblastconditioned medium) stimulation. The table shows genes that are up- or downregulated more than twofold. ND not detected, + only detected in OCM stimulated cells, = unchanged expression. Calculations on fold change are based on the $\Delta \Delta C t$ method on three independent replicates. $* P<0.05$

(matrix Gla protein) levels were demonstrated in OCMstimulated PC-3 cells.

LNCaP-19 stimulates osteoblast proliferation and mineralization

To evaluate the effect of soluble factors from LNCaP-19 on the osteoblastic function, pre-osteoblasts (MC3T3-E1) were stimulated with conditioned medium (CM) derived from CRPC cell lines. The osteoblastic differentiation process is well characterized and consists of distinct phases of proliferation, matrix maturation and mineralization. $\mathrm{CM}$ with soluble factors derived from LNCaP-19 and C4-2B significantly $(P<0.01)$ induced proliferation of pre-osteoblasts to the same extent as PM treated cells $(P<0.01)$, while CM derived from PC-3 and LNCaP had no significant effect on pre-osteoblast proliferation comparable to aMEM control medium (Fig. 2a).

To further assess the effect of CRPC-secreted factors on osteoblastic differentiation, we studied the induction of mRNA expression of established differentiation markers in MC3T3-E1 pre-osteoblasts cultured with CM (Fig. 2b). Factors secreted from LNCaP-19 induced the expression of Alpl, which was sustained over 21 days, a pattern similar to

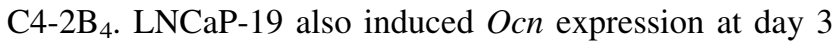
( $\sim 2.9$ fold) compared to aMEM treated control cells, but the mRNA expression declined to control levels at day 7 .
Expression of endogenous osteoprotegerin (Opg), an inhibitor of osteoclast activation, was elevated by LNCaP19 stimulation at day 3 and sustained upregulated at day 7 . The main transcription factors of the osteoblastic lineage, Runx2, Osx and Msx2 were not affected in MC3T3-E1 by CM stimulation (data not shown). In a control experiment, NIH3T3-E1 fibroblasts did not induce any of the osteoblast differentiation markers in response to LNCaP-19 CM (data not shown).

As shown in Fig. 2c, mineralization in osteoblasts was induced by the osteogenic CRPC cell lines, LNCaP-19 and C4-2 $\mathrm{B}_{4}$, while the osteolytic PC-3 and LNCaP did not induce mineralization in osteoblasts. The observed Alp mRNA expression levels (Fig. 2b) and mineralization patterns of osteoblasts (Fig. 2c) were confirmed by staining of Alp activity (Fig. 2d).

LNCaP-19 forms sclerotic lesions in mouse tibia

To evaluate the osteoblastic properties of LNCaP-19 in bone, LNCaP-19 cells were injected directly into bone marrow of tibia in castrated and non-castrated male BALB/ c nude mice. After 10 weeks, 9 out of 13 tibiae of the castrated group and 8 of 13 in the non-castrated group developed tumors. Eight of the castrated and all of the noncastrated mice had tumors that were sclerotic with pronounced ossification. 

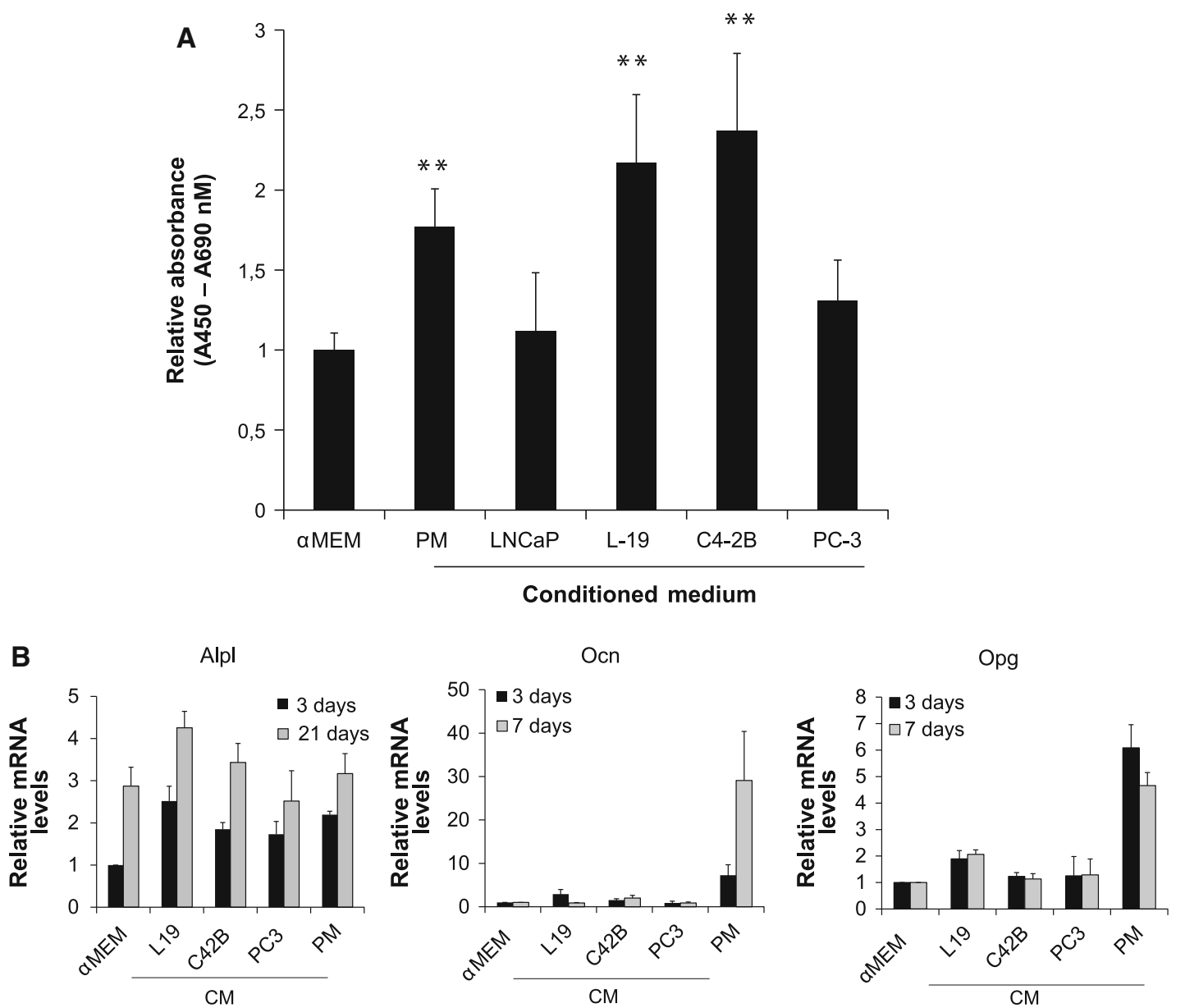

C
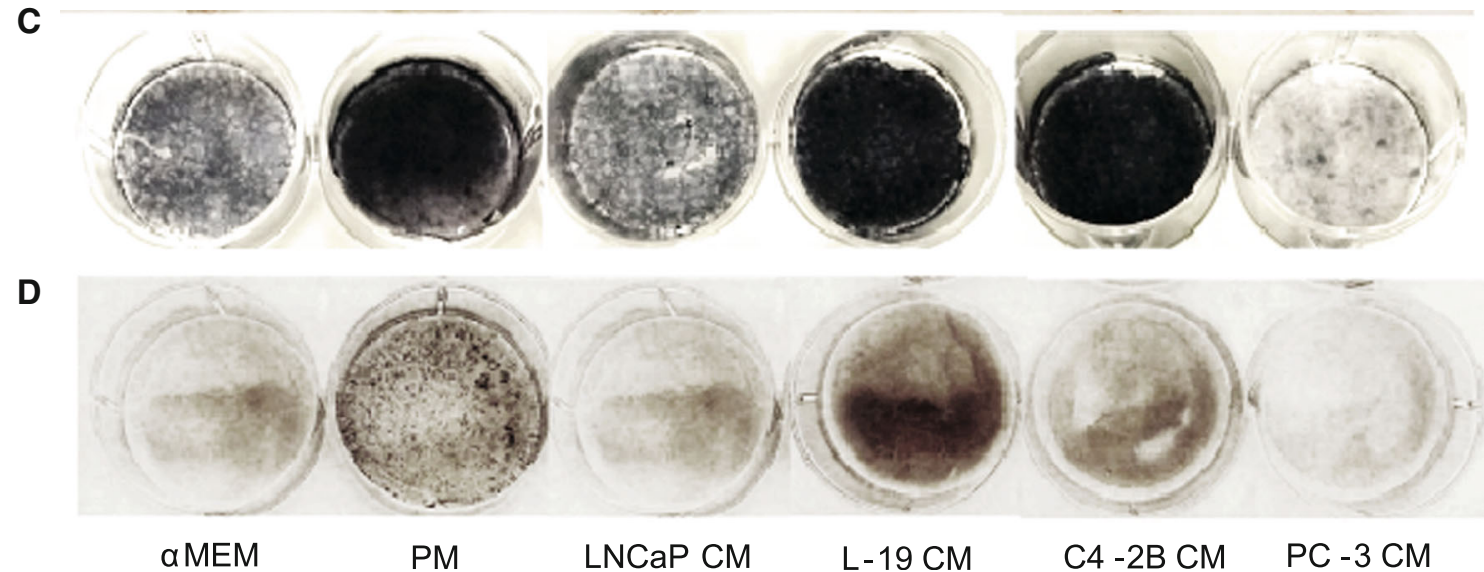

Fig. 2 LNCaP-19 cells affect osteoblast proliferation and mineralization. a Proliferation of MC3T3-E1 $\left(3.5 \times 10^{3}\right.$ cells per well in 96 well plates) was measured by BrdU incorporation after 5 days in culture with aMEM supplemented with $75 \% \mathrm{CM}$. Bars represent mean \pm SEM of three independent experiments. $* * P<0.01$ versus control medium ( $\alpha$ MEM). Total RNA was extracted from MC3T3-E1 pre-osteoblasts at specified days and analyzed for the expression of differentiation markers by RT-qPCR. b Alp1 day 3, and 21, Ocn at day 3 and 7, and $O p g$ at day 3 and 7. The expression levels were normalized to those in control medium ( $\alpha$ MEM). Results are presented as mean \pm SEM of three independent experiments. c For

mineralization assays, MC3T3-E1 pre-osteoblasts were seeded in 6 -well plates $\left(1 \times 10^{5}\right.$ cells/well $)$ and in 12 -well plates $\left(4 \times 10^{4}\right.$ cells/well), for von Kossa staining respectively alkaline phosphatase (Alp) staining. Cells were treated with control medium ( $\alpha M E M)$, conditioned medium $(\mathrm{CM})$ from PC cell lines, or promineralization medium (PM; $\alpha$ MEM supplemented with ascorbic acid $(50 \mu \mathrm{g} / \mathrm{ml})$ and $\beta$-glycerophosphate) $(10 \mathrm{mM})$. All media were supplemented with $10 \%$ FBS. Mineralization of MC3T3-E1 was visualized using von Kossa staining after 21 days in culture. d Staining of Alp activity detected after 21 days in culture 

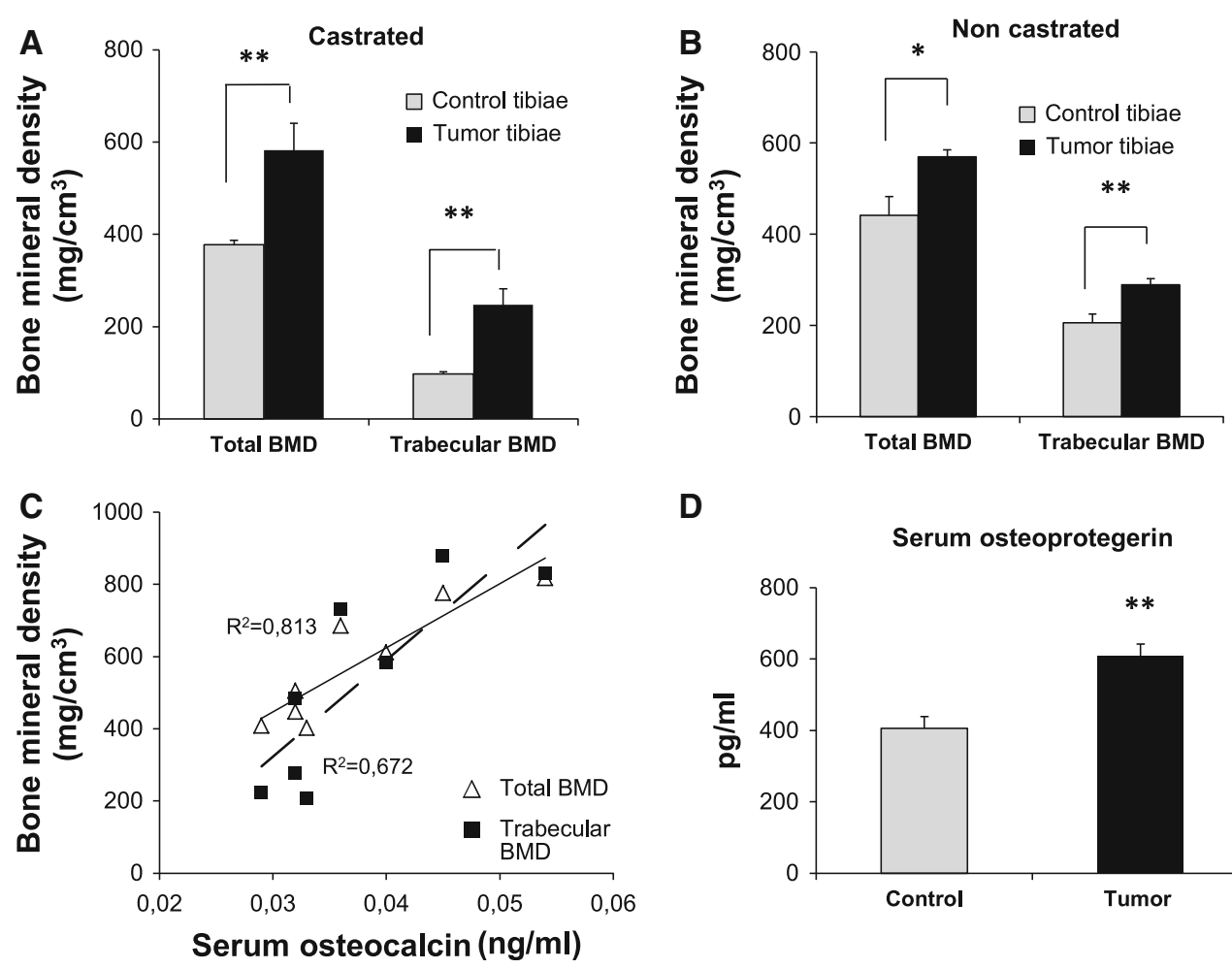

D

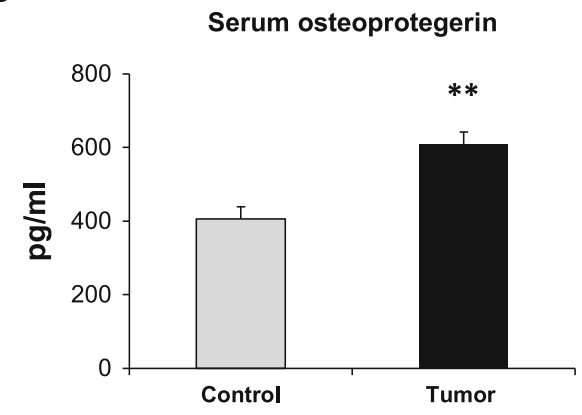

Fig. 3 In vivo properties of LNCaP-19 evaluated as intratibial xenografts after 10 weeks of growth. LNCaP-19 cells $\left(4 \times 10^{5}\right)$ were inoculated into tibia of castrated and non-castrated nude BALB/c mice. The osteosclerotic tumor response was evaluated after 10 weeks. a, b pQCT measurements demonstrate increased total and trabecular BMD in tumor-bearing tibiae compared to control tibiae in a castrated $(n=9)$ and $\mathbf{b}$ non-castrated $(n=8)$ mice. c Mouse-specific ELISA shows correlation between serum

Increased bone formation was demonstrated by an increase in total bone mineral density (BMD) of the tumorbearing tibiae compared to the non-tumor-bearing control tibiae in both castrated $(P<0.001)$ and non-castrated mice $(P<0.028)$. The sclerotic effect was also demonstrated with a pronounced difference of trabecular BMD to the control tibia, in the castrated group $(P<0.002)$ and the non-castrated $(P<0.003)$ (Fig. 3a, b). Ocn is a marker of osteoblast activity and is often elevated during increased bone turnover, for example after castration. The osteoblastic response of LNCaP-19 in castrated mice was also reflected in a strong correlation between serum levels of mouse Ocn and total BMD $\left(R^{2} 0.811, P<0.01\right)$ as well as trabecular BMD $\left(R^{2} 0.673, P<0.05\right)$ (Fig. 3c). There was no significant correlation between Ocn and BMD in the group of non-castrated mice (Total BMD: $R^{2} 0.220$, trabecular BMD: $R^{2}$ 0.243) (data not shown). The sclerotic response in LNCaP-19 tumors may partly depend on inhibited osteoclast activation and osteolysis, since Opg serum level was significantly elevated in tumor bearing castrated and non-castrated mice compared to control mice $(P<0.002)$.

osteocalcin (Ocn) concentrations and BMD in castrated mice, for total BMD $(P<0.01)$ and trabecular BMD $(P<0.05)$, while no correlation was detected in non-castrated mice (data not shown). d The osteoprotegerin (Opg) levels as a response to $\mathrm{LNCaP}-19$ tumors in both castrated and non-castrated tumor bearing mice $(n=8+9)$ were measured by mouse-specific ELISA and compared to control mice. Bars represent mean \pm SEM. $* * P<0.002$

The sclerotic response was clearly demonstrated in the tumor-bearing tibiae of castrated mice with new formed bone replacing the bone marrow cavities, enforced cortex and mineralization in progress (Fig. 4a). An infiltrative growth of prostate carcinoma was demonstrated as interlaced islands of tumor cells within the irregular net of newly formed bone (Fig. 4c). A similar sclerotic response was demonstrated in non-castrated mice (Fig. 4d, f). The injection alone, without tumor cells, did not generate any increased BMD in a control experiment. The control tibiae in castrated mice displayed a total absence of trabecular bone (Fig. 4b) compared to control tibiae in the non-castrated group (Fig. 4e).

\section{Discussion}

Experimental models are important for increased understanding of the complex interplay between tumor and bone cells in PC metastasis. In a new model for studies of osteoblastic tumors of CRPC, which closely mimic the clinical situation, we demonstrate that tumor cell 

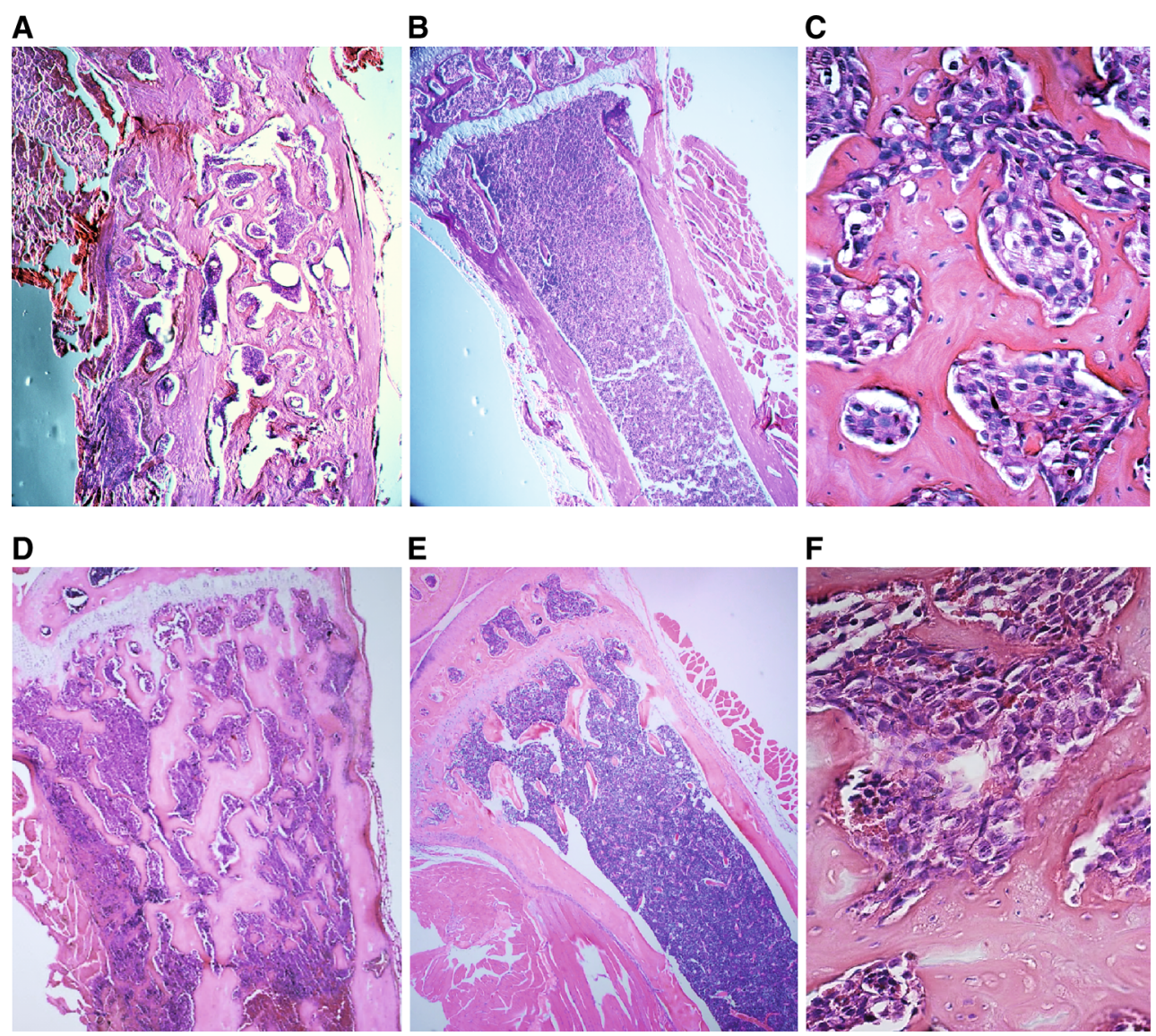

Fig. 4 Histology of the sclerotic tumor response of LNCaP-19. LNCaP-19 cells $\left(4 \times 10^{5}\right)$ were inoculated into tibia of castrated and non-castrated nude BALB/c mice. The osteosclerotic tumor response was evaluated after 10 weeks by histological evaluation of LNCaP-19 in tibiae of castrated and non-castrated mice. a, d Longitudinal sections (H\&E staining) of LNCaP-19 in the tibia, demonstrating new

stimulation by osteoblast-secreted factors is a contributing factor to the vicious cycle of sclerotic bone metastasis of PC.

Since it is known that PC cells acquire bone-like properties during disease progression we performed an osteogenic profiling of castration-resistant LNCaP-19 and its parental androgen-dependent cell line LNCaP. A basal expression of bone-related genes in favour of an osteoblastic response was detected in both cell lines, while expression of genes associated with osteolytic events and osteoclastogenesis was low or undetectable. However, there is a major difference between the two cell lines regarding the osteogenic properties; LNCaP-19 is able to mineralize extra cellular bone matrix whereas LNCaP lack this ability. In accordance with its capacity to mineralize, LNCaP-19 expresses genes such as $C O L 1 A 1$ and $D S P P$, both crucial for the mineralization process, while their mRNA expression was undetectable in $\mathrm{LNCaP}$ cells. Therefore, our data suggest that the basal osteomimetic properties of $\mathrm{LNCaP}-19$ are formed bone replacing the bone marrow cavity (magnification $\times 200$ ). b, e Control tibiae without tumor cell injection (magnification $\times 200$ ). c, f Islands of interlaced LNCaP-19 cells within the newly formed trabecular bone (magnification $\times 400$ ). a-c represent tibiae from castrated mice and $\mathbf{d}-\mathbf{f}$ non-castrated

the result of the acquisition of castration-resistance and may explain part of the tropism of CRPC cells to bone.

It has previously been demonstrated that a number of proteins, such as Osn, Opn and Ocn, directly associated with bone growth and osteoblast activity are overexpressed in tumor cells during the transformation of PC cells into a castration-resistant state $[16,29,30]$. In accordance with those previous studies, and indicating the importance of castration-resistance in osteomimicry, these genes, except for Ocn, are highly expressed in LNCaP-19 as compared to LNCaP. However, the mRNA expression of Osn, Opn and Ocn was directly induced in LNCaP by osteoblast-stimulation, suggesting that osteoblasts can promote an osteogenic phenotype prior to castration-resistance.

To further characterize LNCaP-19 as an osteogenic CRPC model, we compared the bone-associated gene profile of LNCaP-19 with other CRPC cell lines. Compared to both the parental androgen-dependent $\mathrm{LNCaP}$ and the in vivo derived osteoblastic castration-resistant cell line 
C4-2B 4 , LNCaP-19 expressed several genes associated with osteoblastic properties that were not expressed in the other cell lines (CDH11,COLIA1 and SPPI), which could explain its osteoblastic potential also in steroid deprived conditions. The absence of $R U N X 2$ expression in $\mathrm{C} 4-2 \mathrm{~B}_{4}$ in basal steroid deprived conditions is a striking difference, which could possibly be due to the fact that $\mathrm{C} 4-2 \mathrm{~B}_{4}$ was derived in vivo, from a bone metastasis from $\mathrm{C} 4-2$ [22]. Thus, the osteoblastic function of $\mathrm{C} 4-2 \mathrm{~B}_{4}$ in vivo may be dependent on the presence of bone cells to induce RUNX2, which was also demonstrated in vitro in the present study. In contrast, LNCaP-19, which is developed in vitro without influence from bone, has the full osteogenic gene programme activated independent of osteoblast stimulation.

The strongly osteolytic cell line PC-3 displayed most of the osteogenic profile but in contrast to LNCaP-19 also expressed a different set of genes strongly associated with osteoblast inhibitory and osteolytic events, such as BMP3, TWIST2 and CSF2 and -3 . This observation suggests that the expression of these genes may prevent the ability of PC-3 to mineralize or to induce mineralization in osteoblasts. Moreover, the bone-forming genes that were observed to be elevated in response to osteoblast-derived factors in LNCaP-19 in comparison to PC-3 cells, suggesting that soluble osteoblast-derived factors increase the osteogenic potential of osteogenic CRPC cells, while the effect on osteolytic cells is minor.

The observation that LNCaP-19 has the capacity to mineralize matrix without osteoblast stimulation suggests that osteomimicry can be an inherent property in advanced $\mathrm{PC}$, independent of bone stimulation. Interestingly, LNCaP-19 was derived from a lymph node metastasis and further progressed by androgen deprivation in vitro, and thus has never experienced contact with the bone environment. However, osteogenic capacity has previously been demonstrated in other CRPC cell lines $\left(\mathrm{C}_{4}-2 \mathrm{~B}_{4}\right.$, MDA-PCa 2a and 2b) [19, 28], but in contrast to LNCaP19 these cell lines are derived from bone implants and may therefore have adopted phenotypic changes in the bone milieu.

Osteoblast-secreted factors induced a phenotypic shift of LNCaP-19 cells, including morphological changes, increased proliferation and capacity to mineralize matrix. Interestingly, this phenotypic shift of LNCaP-19 is associated with elevated expression of genes related to tumor aggressiveness and metastasis of CRPC. Among these was $R U N X 2$, the main transcription factor of osteoblast differentiation, which has previously been found to be ectopically expressed in metastatic cancer cells [31-33]. In PC, Runx 2 expression increases with disease progression where it can induce an aggressive gene expression program, including normally weakly expressed genes such as MMP2 $[34,35]$. This indicates a different regulatory role of Runx2 when ectopically expressed in tumor cells. Moreover, it has been shown that mineralization of $\mathrm{C} 4-2 \mathrm{~B}_{4}$ was induced by Runx2 [28]. This suggests that RUNX2 have an important role in the development of the osteogenic phenotype of CRPC. The relatively weak response of $\mathrm{C} 4-2 \mathrm{~B}_{4}$ to $\mathrm{OCM}$ stimulation may be a result of the conditions under which it was developed. The growth in bone may have selected for cells that were well adapted to that microenvironment, and as a result an additional OCM stimulation in vitro does not dramatically change its phenotype. However, in vitro OCM stimulation induced expression of fibroblast factor $1(F G F 1)$ and $-2(F G F 2)$ exclusively in $\mathrm{C}^{2}-2 \mathrm{~B}_{4}$ cells. Since FGF1 has been shown to prevent osteoporosis in a rat model [36], this could suggest a different sclerotic mechanism in bone-derived CRPC cells compared to CRPC cells that have never been in contact with bone, such as LNCaP-19.

The vicious cycle involving tumor- and bone cells in osteolytic metastases from breast and lung cancer has been well characterized [37]. However, the vicious cycle of osteoblasts and PC tumor cells in the sclerotic situation is poorly understood. The upregulated expression of $\mathrm{CDH} 11$ and $M M P 2$ in $\mathrm{LNCaP}-19$ in response to OCM indicates induction of an increased potential for interaction between osteoblasts and PC cells in the formation of bone metastases [38, 39]. Recently, MMP2 was identified as a key factor of the vicious cycle of osteoblasts and metastatic tumor cells [40]. The $C D H 11$, also known as osteoblastcadherin, is reported to be highly expressed in bone metastases and bone-derived PC cell lines. Moreover, CDH11 was previously reported to mediate cell-invasion and adhesion between PC cells and osteoblasts [38, 39]. Alterations of $\mathrm{CDH} 11$ are suggested to be partly responsible for the bone-tropism of PC. The expression of MMP2 and $C D H 11$ in LNCaP-19 and PC-3 in comparison to $\mathrm{LNCaP}$ and elevated expression levels of these genes upon OCM stimulation in LNCaP-19, suggests that castrationresistance potentiates the communication between tumor cells and osteoblasts.

In addition to osteoblast-induced changes in CRPC cells, we demonstrate that LNCaP-19 stimulates pre-osteoblasts to differentiate, proliferate and mineralize in a manner similar to other osteoblastic CRPC models [19, 28]. Previous studies have reported that stimulation by CRPC cells led to a significantly increase in an immature population of osteoblasts [28, 41]. In accordance with this, we demonstrated the effect of LNCaP-19 stimulation on osteoblasts including an early induction of $O c n$ on day 3 and maintained expression of $\mathrm{Alpl}$ over the differentiation process. Taken together, these findings are in agreement with clinical observations of CRPC metastases, which are composed of a high proportion of immature new woven bone and non-mineralized matrix [42], which is also clinically 
reflected by increasing Alp levels in serum accompanied by a modest increase of Ocn [43]. Ocn is a marker of mature osteoblasts and is normally induced at a later stage than Alp, which is necessary for the initiation but not for continuation of mineralization during osteoblast differentiation [44]. In line with previous observations, the altered pattern of differentiation markers expressed in osteoblasts accompanied by a different staining pattern of mineralization and increased proliferation, suggests that LNCaP-19 cells stimulate an immature population of osteoblasts that contributes to the major part of the newly synthesized bone. In addition, the positive correlation between serum Ocn and BMD in the in vivo system, supports evidence for increased osteoblast activity in response to LNCaP-19.

Osteoblasts can regulate bone metabolism by modulating the bone resorption process, directly via the production of receptor activator of nuclear factor $\kappa \beta$ ligand (RANKL) and negatively via the secretion of its decoy receptor Opg $[45,46]$. In the present study, the elevated mRNA expression of $\mathrm{Opg}$ and serum level of Opg in osteoblasts and tumor bearing mice respectively, in response to LNCaP-19, suggest a local suppression of osteoclast activation which could contribute to the overall osteoblastic response in CRPC tumors.

Furthermore, the present study demonstrates the capacity of LNCaP-19 to form sclerotic lesions in bone upon intratibial implantation in both castrated and non-castrated mice. Interestingly, LNCaP-19 was shown to induce an osteoblastic response in tibiae of castrated mice with increased BMD. This in contrasts to the commonly used LNCaP bone-derived C4-2 model, which under castrated conditions results in mixed osteoblastic/osteolytic lesions with an overall decrease in BMD [47]. We also demonstrate that in castrated mice, BMD positively correlate with Ocn serum levels, indicating additional tumor-induced osteoblast activity in the castrated compared to the noncastrated situation.

With similarity to clinical observations [42], the LNCaP19 tumors in tibia show characteristics of an osteoblastic tumor response (i.e. osteodense bone without resorption). The newly formed bone was observed in the marrow spaces, not adjacent to the cortical bone surface associated with osteoclast-dependent bone resorption as occurs in the normal bone formation.The pattern of irregularly formed trabecular bone, interlaced with islands of tumor cells closely mimics a metastatic prostate adenocarcinoma in humans, rendering this model useful for in vivo evaluation.

In conclusion, our work presents a model, closely mimicking the clinical situation, for studies of the osteoblastic function of CRPC both in vitro and in vivo. We here show that osteomimicry can be an inherent feature of CRPC cells, which is further promoted by osteoblast stimulation. Moreover, osteoblast-secreted factors trigger the aggressiveness of CRPC cells and potentiate cross-talk between tumor- and bone cells in the sclerotic situation. Collectively these results indicate that targeting the communication between osteoblasts and PC cells could inhibit the progression of bone metastases in CRPC.

\section{Materials and methods}

Cell lines and culture conditions

The androgen-dependent PC cell line LNCaP, FGC clone, was obtained from the American Type Culture Collection (ATCC, Rockville, MD). LNCaP-19 a CRPC cell line, derived from $\mathrm{LNCaP}$ by androgen deprivation, was established in vitro in our laboratory [23]. PC-3 was obtained from the European Collection of Cell Cultures (ECCC, Wiltshire, UK). C4-2B 4 was kindly provided by Professor Thalmann, Dept of Urology, University of Bern, Switzerland. PC cells were routinely maintained in RPMI1640 supplemented with glucose, sodium pyruvate (PAA), $10 \%$ foetal bovine serum (FBS, Invitrogen, Carlsbad, CA) (LNCaP, PC-3 and C4-2B $\mathrm{B}_{4}$ ) or $10 \%$ dextrane charcoal-treated FBS (FBS-DCC, Invitrogen) (LNCaP-19). Pre-osteoblasts, MC3T3-E1 cells, clone 4, were obtained from the ATCC (Rockville, MD). Osteoblasts were maintained in ascorbic acid (AA) free $\alpha \mathrm{MEM}$ (Invitrogen) and $10 \%$ FBS. Murine fibroblasts (NIH3T3, ATCC) were maintained in DMEM (Invitrogen) supplemented with $10 \%$ FBS. All cultures were supplemented with penicillin/streptomycin. Passage numbers between 17 and 21 were used for LNCaP-19 cells and passage numbers 5-9 for $\mathrm{PC}-3$ and $\mathrm{C} 4-2 \mathrm{~B}_{4}$. For osteoblasts and fibroblasts, passage numbers between 3 and 8 were used in the experiments. Passage number 1 is defined as the first passage in our laboratory.

To induce mineral production, cells were cultured in promineralization medium (PM) consisting of $\alpha \mathrm{MEM}$ supplemented with $10 \mathrm{mM} \quad \beta$-glycerophosphate (Sigma Chemical Co., St. Louis, MO, USA) and $50 \mathrm{mg} / \mathrm{ml} \mathrm{L-AA}$ (Sigma) or cell-conditioned medium (CM) for 21 days.

\section{Conditioned medium}

Cell-conditioned medium (CM) was obtained to assess the effects of secreted factors produced by osteoblasts and CRPC cells on gene expression level, proliferation and mineralization. Cells were seeded in T75 flasks and grown to 70-80\% confluence in their respective media, cells were washed with PBS and medium was replaced with serumfree $\alpha \mathrm{MEM}$. CM was collected after $48 \mathrm{~h}$ culture. The cell number was determined and CM was adjusted by dilution in serum-free medium to normalize for differences in cell 
density. CM was centrifuged to remove cell debris and stored at $-20{ }^{\circ} \mathrm{C}$ until use. Maximal final concentration of $\mathrm{CM}$ used in the experiments was $75 \%$.

Abbreviations used: CM (CRPC-conditioned medium from $\mathrm{LNCaP}-19, \mathrm{C} 4-2 \mathrm{~B}_{4}, \mathrm{PC}-3$, and $\left.\mathrm{LNCaP}\right), \mathrm{OCM}$ (osteoblast-conditioned medium from MC3T3-E1) and FCM (fibroblast-conditioned medium from NIH3T3).

\section{Osteoblast differentiation}

Osteoblasts were seeded in T25 flasks $\left(3 \times 10^{5}\right)$ as described above. After $48 \mathrm{~h}$, cells were washed with PBS and standard medium was replaced with $\alpha$ MEM, PM or CM. Cell culture medium for osteoblasts and fibroblasts was supplemented with $10 \%$ FBS. For studies of osteoblastic differentiation markers, cultures were maintained in CM for 3, 7 or 21 days, when cells were harvested for RNA extraction. Medium was changed every 3 days.

\section{Cell proliferation}

Osteoblasts were seeded in 96 well plates at a density of $3.5 \times 10^{3}$ cells per well in $\alpha$ MEM with $10 \%$ FBS in four replicates for each treatment. On day 2, medium was changed to CM, PM or control medium ( $\mathrm{\alpha MEM}$ ). Since osteoblasts are dependent on serum for survival in culture, all medium was supplemented with $10 \%$ FBS. LNCaP-19 cells were seeded at a density of $5.0 \times 10^{3}$ cells per well in aMEM with $1 \%$ DCC. Medium was replaced on day two with OCM, FCM, or control medium (CM from LNCaP19; L19CM), supplemented with $1 \%$ FBS-DCC. Proliferation was monitored by the BrdU ELISA colorimetric assay (Roche Diagnostics, Indianapolis, IN) in accordance with the manufacturer's instructions after $48,96 \mathrm{~h}$ (LNCaP-19) and 5 days (MC3T3-E1). Stop solution (1 M $\mathrm{H}_{2} \mathrm{SO}_{4}$ ) was added and plates were read in a Wallac 1420 Victor ${ }^{\mathrm{TM}}$ multiplate reader (PerkinElmer, Inc, Shelton, CT) at a $450 \mathrm{~nm}$ with reference filter at a $690 \mathrm{~nm}$.

Detection of mineralization with von Kossa and alkaline phosphatase staining

MC3T3-E1, LNCaP and LNCaP-19 cells were seeded in six well plates at a density of $1 \times 10^{5}$ or $2 \times 10^{5}$ cells per well in $\alpha$ MEM with $10 \%$ FBS or RPMI-1640 with $10 \%$ FBSDCC, respectively. After $48 \mathrm{~h}$, medium was changed to CM, OCM or PM and mineral deposition was determined by von Kossa or alkaline phosphatase staining after 21 days. Briefly, for von Kossa, cells were washed with PBS and fixed with $95 \%$ ice cold ethanol. For calcium retention, the fixed cells were exposed to $60 \mathrm{~W}$ UV light in a solution of $5 \%$ silver nitrate for $60 \mathrm{~min}$ for visualization. Alkaline phosphatase (Alp) is a marker of proliferating osteoblasts and is greatly enhanced during in vitro bone formation. In brief, MC3T3-E1 and LNCaP-19 cells were fixed for $60 \mathrm{~s}$ using neutral buffered formalin $(10 \%)$ and washed with PBS + 0, 05 TWEEN 20. BCIP/NBT (Sigma; 5-bromo-4chloro-3-indolyl phosphate/nitro blue tetrazolium) substrate solution was added to the monolayer and incubated in dark for $25 \mathrm{~min}$ and washed before visualization. For the mineralization assays, medium was changed every 3 days.

\section{RNA isolation and RT-qPCR}

Total RNA was extracted using RNeasy Mini Plus kit (Qiagen, Valencia, CA) in accordance with the manufacturer's instructions. RNA concentration was measured on a NanoDrop (Thermo Fisher Scientific Inc, Wilmington, $\mathrm{DE})$. A total of $1 \mu \mathrm{g}$ RNA per reaction was reversely transcribed into cDNA using the VILO Superscript cDNA synthesis kit (Invitrogen) in accordance with the manufacturer's instructions. RT-qPCR was performed using an ABI Prism 7500 Fast Sequence Detector (Applied Biosystems, Foster City, CA) and specific TaqMan probes as follows: mouse runt-related transcription factor 2 (Runx2) (Cbfa1;Mm00501584), osterix (Osx) (Mm00501584_m1), msh homeobox 2 (Msx2) (Mm00442992_m1), alkaline phosphatase (Alpl) (Mm01187117_m1) osteocalcin (Ocn) (Bglap;Mm03413826_m1), osteoprotegerin (Opg) (Mm01205928_m1) and endogenous control 18S rRNA (Hs99999901), purchased as TaqMan Gene Expression Assays (Applied Biosystems). PCR parameters were in accordance with the manufacturer's protocol and the $\Delta \Delta C t$ method was used for relative mRNA quantification. The expression levels of each sample were normalized against 18S rRNA and PCR reactions for target genes, and controls were performed in triplicates for all samples.

\section{Osteogenesis gene signature array}

Expression of bone-related genes in LNCaP-19, $\mathrm{LNCaP}$ and PC-3 were evaluated using a human osteogenesis gene signature array (Applied Biosystems: TaqMan ${ }^{\circledR}$ Array Gene Signature Plate \#4418741). The array included 96 osteogenesis-related genes and endogenous control genes (for a complete list of genes included, see www.appliedbiosystems. com). The array was used to evaluate the basal osteogenic expression profile of $\mathrm{LNCaP}-19, \mathrm{LNCaP}, \mathrm{C} 4-2 \mathrm{~B}_{4}$ and PC-3 with or without stimulation with OCM. Briefly, cells were seeded in T25 flasks in an optimized density (LNCaP and LNCaP-19, $1 \times 10^{6}, \mathrm{C} 4-2 \mathrm{~B}, 8 \times 10^{5}$ and PC-3, $6 \times 10^{5}$ ) to reach $80 \%$ confluence after $24 \mathrm{~h}$. Cells were starved for $24 \mathrm{~h}$ before medium was replaced with control medium or OCM supplemented with $1 \%$ FBS-DCC. Cultures were maintained for $48 \mathrm{~h}$ before RNA extraction, as previously described. A total of $5 \mu \mathrm{g}$ cDNA/reaction was used for the 
PCR reactions. Parameters were set up in accordance with the manufacturer's protocol and the $\Delta \Delta C t$ method was used for relative mRNA quantification. The expression levels of each sample were normalized against HPRT1 (Hs99999909_m1) and GUSB (Hs99999908_m1). Only target genes with the most significant variations are shown (twofold regulation). Genes were considered as non-detected in cases where $C t$ values were above 36 . Gene expression analysis was performed in independent triplicates.

\section{Xenograft model and bone impact analyses}

An intrabone injection in vivo model was used to confirm the osteoblastic phenotype induced by LNCaP-19 in vitro. Eight-week-old male BALB/c nude mice (Charles River, Wilmington, MA) were castrated via scrotal incision under anaesthesia. LNCaP-19 cells were then injected into the left tibia using a procedure similar to what has previously been described $[18,27]$. Briefly, the left leg of the mouse was flexed to a $90^{\circ}$ angle and a $29 \mathrm{G}$ needle was inserted, via the knee joint, into the proximal end of tibia using a drilling motion. 400,000 LNCaP-19 cells suspended in $7 \mu \mathrm{l}$ matrigel (BD Bioscience, Franklin Lakes, NJ) were injected directly into the bone marrow cavity. Animals received analgesics (Rimadyl; $5 \mathrm{mg} / \mathrm{kg}$ ) the following 5 days. The experiment was ended after 10 weeks. Blood was collected and stored as serum at $-70{ }^{\circ} \mathrm{C}$ until analysis. Tibiae were dissected and bone mineral density (BMD) was obtained from CT scans of tibiae using pQCT XCT RESEARCH M (version 4.5B: Norland, Ft. Atkinson, WI). For each mouse, the right tibia was used as non-tumor-bearing control. For histological evaluation, tibiae were fixed in formalin, decalcified in modified formic acid (Histolab, Sweden) and embedded in paraffin. Tumor establishment was assessed in $4 \mu \mathrm{m}$ thick hematoxylin and eosin (H\&E) stained sections of the central part of the bone marrow.

Ethics statement: This study was carried out in strict accordance with the recommendations in the Guide for the Care and Use of Laboratory Animals of the National Institutes of Health. The protocol was approved by the local Committee on the Ethics of Animal Experiments of Gothenburg (Permit Number: 109-2008). All surgery was performed under anaesthesia, and all efforts were made to minimize suffering.

\section{ELISA}

Serum levels of Ocn, a marker of osteoblast activity and Opg, an inhibitor of osteoclast activity, were measured using mouse-specific ELISAs in accordance with the manufacturer's instructions (Ocn; Demeditec Diagnostics GmbH, Germany, Opg; Abcam, Cambridge, UK). Serum was diluted 1:10 and absorbance was read at $450 \mathrm{~nm}$ in a Wallac 1420 Victor $^{\mathrm{TM}}$ multiplate reader (PerkinElmer Inc, Shelton, CT).

\section{Statistics}

Statistical calculations were performed using the SPSSv 20 software package (SPSS, Chicago, USA). Statistical differences between groups were performed using Student's $t$ Test or Mann-Whitney $U$ Test where appropriate. Statistical significance of BMD was determined by MannWhitney $U$ test. Correlation was determined with Spearman's rank correlation test. All data are presented as mean \pm SEM. A $P$ value of $<0.05$ was considered significant.

Acknowledgments We gratefully thank Anita Fae for excellent technical assistance with the animal experiments and Anette Hansevi for excellent technical assistance with the CT measurements. This study was funded by grants from the Swedish Cancer Society, ALF/ Västra Götalandsregionen, ProLiv Väst, the Wilhelm \& Martina Lundgren Foundation, Sahlgrenska University Hospital and the Assar Gabrielsson Foundation for Clinical Research.

Open Access This article is distributed under the terms of the Creative Commons Attribution License which permits any use, distribution, and reproduction in any medium, provided the original author(s) and the source are credited.

\section{References}

1. Michaelson MD, Marujo RM, Smith MR (2004) Contribution of androgen deprivation therapy to elevated osteoclast activity in men with metastatic prostate cancer. Clin Cancer Res 10(8):2705-2708

2. Vessella RL, Corey E (2006) Targeting factors involved in bone remodeling as treatment strategies in prostate cancer bone metastasis. Clin Cancer Res 12(20 Pt 2):6285s-6290s. doi:10. 1158/1078-0432.CCR-06-0813

3. Oefelein MG, Ricchuiti V, Conrad W, Seftel A, Bodner D, Goldman H, Resnick M (2001) Skeletal fracture associated with androgen suppression induced osteoporosis: the clinical incidence and risk factors for patients with prostate cancer. J Urol 166(5):1724-1728

4. Mundy GR (2002) Metastasis to bone: causes, consequences and therapeutic opportunities. Nat Rev Cancer 2(8):584-593. doi:10. $1038 / \mathrm{nrc} 867$

5. Roodman GD (2004) Mechanisms of bone metastasis. N Engl J Med 350(16):1655-1664. doi:10.1056/NEJMra030831

6. Jung K, Lein M, Stephan C, Von Hosslin K, Semjonow A, Sinha P, Loening SA, Schnorr D (2004) Comparison of 10 serum bone turnover markers in prostate carcinoma patients with bone metastatic spread: diagnostic and prognostic implications. Int $\mathbf{J}$ Cancer 111(5):783-791. doi:10.1002/ijc.20314

7. Roudier MP, True LD, Higano CS, Vesselle H, Ellis W, Lange P, Vessella RL (2003) Phenotypic heterogeneity of end-stage prostate carcinoma metastatic to bone. Hum Pathol 34(7):646-653

8. Shimazaki J, Higa T, Akimoto S, Masai M, Isaka S (1992) Clinical course of bone metastasis from prostatic cancer 
following endocrine therapy: examination with bone X-ray. Adv Exp Med Biol 324:269-275

9. Autzen P, Robson CN, Bjartell A, Malcolm AJ, Johnson MI, Neal DE, Hamdy FC (1998) Bone morphogenetic protein 6 in skeletal metastases from prostate cancer and other common human malignancies. Br J Cancer 78(9):1219-1223

10. Lee HL, Pienta KJ, Kim WJ, Cooper CR (2003) The effect of bone-associated growth factors and cytokines on the growth of prostate cancer cells derived from soft tissue versus bone metastases in vitro. Int J Oncol 22(4):921-926

11. Nelson JB, Hedican SP, George DJ, Reddi AH, Piantadosi S, Eisenberger MA, Simons JW (1995) Identification of endothelin1 in the pathophysiology of metastatic adenocarcinoma of the prostate. Nat Med 1(9):944-949

12. Fizazi K, Yang J, Peleg S, Sikes CR, Kreimann EL, Daliani D, Olive M, Raymond KA, Janus TJ, Logothetis CJ, Karsenty G, Navone NM (2003) Prostate cancer cells-osteoblast interaction shifts expression of growth/survival-related genes in prostate cancer and reduces expression of osteoprotegerin in osteoblasts. Clin Cancer Res 9(7):2587-2597

13. Wang G, Haile S, Comuzzi B, Tien AH, Wang J, Yong TM, Jelescu-Bodos AE, Blaszczyk N, Vessella RL, Masri BA, Sadar MD (2009) Osteoblast-derived factors induce an expression signature that identifies prostate cancer metastasis and hormonal progression. Cancer Res 69(8):3433-3442. doi:10.1158/00085472.CAN-08-3506

14. Clines GA, Guise TA (2005) Hypercalcaemia of malignancy and basic research on mechanisms responsible for osteolytic and osteoblastic metastasis to bone. Endocr Relat Cancer 12(3):549-583. doi:10.1677/erc. 1.00543

15. Gardner TA, Lee SJ, Lee SD, Li X, Shirakawa T, Kwon DD, Park RY, Ahn KY, Jung C (2009) Differential expression of osteocalcin during the metastatic progression of prostate cancer. Oncol Rep 21(4):903-908

16. Koeneman KS, Yeung F, Chung LWK (1999) Osteomimetic properties of prostate cancer cells: a hypothesis supporting the predilection of prostate cancer metastasis and growth in the bone environment. Prostate 39(4):246-261

17. Rucci N, Teti A (2010) Osteomimicry: how tumor cells try to deceive the bone. Front Biosci (Schol Ed) 2:907-915

18. Corey E, Quinn JE, Bladou F, Brown LG, Roudier MP, Brown JM, Buhler KR, Vessella RL (2002) Establishment and characterization of osseous prostate cancer models: intra-tibial injection of human prostate cancer cells. Prostate 52(1):20-33. doi:10. 1002/pros.10091

19. Yang J, Fizazi K, Peleg S, Sikes CR, Raymond AK, Jamal N, Hu M, Olive M, Martinez LA, Wood CG, Logothetis CJ, Karsenty G, Navone NM (2001) Prostate cancer cells induce osteoblast differentiation through a Cbfa1-dependent pathway. Cancer Res 61(14):5652-5659

20. Al Nakouzi N, Bawa O, Le Pape A, Lerondel S, Gaudin C, Opolon P, Gonin P, Fizazi K, Chauchereau A (2012) The IGR$\mathrm{CaP1}$ xenograft model recapitulates mixed osteolytic/blastic bone lesions observed in metastatic prostate cancer. Neoplasia 14(5):376-387

21. Raheem O, Kulidjian AA, Wu C, Jeong YB, Yamaguchi T, Smith KM, Goff D, Leu H, Morris SR, Cacalano NA, Masuda K, Jamieson CH, Kane CJ, Jamieson CA (2011) A novel patient-derived intrafemoral xenograft model of bone metastatic prostate cancer that recapitulates mixed osteolytic and osteoblastic lesions. J Transl Med 9:185. doi:10.1186/1479-5876-9-185

22. Thalmann GN, Anezinis PE, Chang SM, Zhau HE, Kim EE, Hopwood VL, Pathak S, von Eschenbach AC, Chung LW (1994) Androgen-independent cancer progression and bone metastasis in the LNCaP model of human prostate cancer. Cancer Res 54(10):2577-2581
23. Gustavsson H, Welen K, Damber JE (2005) Transition of an androgen-dependent human prostate cancer cell line into an androgen-independent subline is associated with increased angiogenesis. Prostate 62(4):364-373. doi:10.1002/pros.20145

24. Jennbacken K, Gustavsson H, Welen K, Vallbo C, Damber JE (2006) Prostate cancer progression into androgen independency is associated with alterations in cell adhesion and invasivity. Prostate 66(15):1631-1640. doi:10.1002/Pros.20469

25. Gustavsson H, Jennbacken K, Welen K, Damber JE (2008) Altered expression of genes regulating angiogenesis in experimental androgen-independent prostate cancer. Prostate 68(2):161-170. doi:10.1002/Pros.20672

26. Jennbacken K, Tesan T, Wang WZ, Gustavsson H, Damber JE, Welen K (2010) N-cadherin increases after androgen deprivation and is associated with metastasis in prostate cancer. Endocr Relat Cancer 17(2):469-479. doi:10.1677/Erc-10-0015

27. Jennbacken K, Welen K, Olsson A, Axelsson B, Torngren M, Damber JE, Leanderson T (2011) Inhibition of metastasis in a castration resistant prostate cancer model by the quinoline-3carboxamide tasquinimod (ABR-215050). Prostate. doi:10.1002/ pros. 21495

28. Lin DL, Tarnowski CP, Zhang J, Dai JL, Rohn E, Patel AH, Morris MD, Keller ET (2001) Bone metastatic LNCaP-derivative C4-2B prostate cancer cell line mineralizes in vitro. Prostate 47(3):212-221. doi:10.1002/pros.1065

29. Thalmann GN, Sikes RA, Devoll RE, Kiefer JA, Markwalder R, Klima I, Farach-Carson CM, Studer UE, Chung LWK (1999) Osteopontin: possible role in prostate cancer progression. Clin Cancer Res 5(8):2271-2277

30. Thomas R, True LD, Bassuk JA, Lange PH, Vessella RL (2000) Differential expression of osteonectin/SPARC during human prostate cancer progression. Clin Cancer Res 6(3):1140-1149

31. Barnes GL, Hebert KE, Kamal M, Javed A, Einhorn TA, Lian JB, Stein GS, Gerstenfeld LC (2004) Fidelity of Runx2 activity in breast cancer cells is required for the generation of metastasesassociated osteolytic disease. Cancer Res 64(13):4506-4513. doi:10.1158/0008-5472.CAN-03-3851

32. Javed A, Barnes GL, Pratap J, Antkowiak T, Gerstenfeld LC, van Wijnen AJ, Stein JL, Lian JB, Stein GS (2005) Impaired intranuclear trafficking of Runx2 (AML3/CBFA1) transcription factors in breast cancer cells inhibits osteolysis in vivo. Proc Natl Acad Sci USA 102(5):1454-1459. doi:10.1073/pnas.0409121102

33. Pratap J, Imbalzano KM, Underwood JM, Cohet N, Gokul K, Akech J, van Wijnen AJ, Stein JL, Imbalzano AN, Nickerson JA, Lian JB, Stein GS (2009) Ectopic runx2 expression in mammary epithelial cells disrupts formation of normal acini structure: implications for breast cancer progression. Cancer Res 69(17):6807-6814. doi:10.1158/0008-5472.CAN-09-1471

34. Akech J, Wixted JJ, Bedard K, van der Deen M, Hussain S, Guise TA, van Wijnen AJ, Stein JL, Languino LR, Altieri DC, Pratap J, Keller E, Stein GS, Lian JB (2010) Runx2 association with progression of prostate cancer in patients: mechanisms mediating bone osteolysis and osteoblastic metastatic lesions. Oncogene 29(6):811-821. doi:10.1038/onc.2009.389

35. Baniwal SK, Khalid O, Gabet Y, Shah RR, Purcell DJ, Mav D, Kohn-Gabet AE, Shi Y, Coetzee GA, Frenkel B (2010) Runx2 transcriptome of prostate cancer cells: insights into invasiveness and bone metastasis. Mol Cancer 9:258. doi:10.1186/1476-45989-258

36. Dunstan CR, Boyce R, Boyce BF, Garrett IR, Izbicka E, Burgess WH, Mundy GR (1999) Systemic administration of acidic fibroblast growth factor (FGF-1) prevents bone loss and increases new bone formation in ovariectomized rats. J Bone Miner Res 14(6):953-959. doi:10.1359/jbmr.1999.14.6.953

37. Guise TA, Mohammad KS, Clines G, Stebbins EG, Wong DH, Higgins LS, Vessella R, Corey E, Padalecki S, Suva L, Chirgwin 
JM (2006) Basic mechanisms responsible for osteolytic and osteoblastic bone metastases. Clin Cancer Res 12(20):6213s6216s. doi:10.1158/1078-0432.Ccr-06-1007

38. Lee YC, Cheng CJ, Huang M, Bilen MA, Ye XC, Navone NM, Chu K, Kao HH, Yu-Lee LY, Wang ZX, Lin SH (2010) Androgen depletion up-regulates cadherin-11 expression in prostate cancer. J Pathol 221(1):68-76. doi:10.1002/Path.2687

39. Huang CF, Lira C, Chu K, Bilen MA, Lee YC, Ye XC, Kim SM, Ortiz A, Wu FLL, Logothetis CJ, Yu-Lee LY, Lin SH (2010) Cadherin-11 increases migration and invasion of prostate cancer cells and enhances their interaction with osteoblasts. Cancer Res 70(11):4580-4589. doi:10.1158/0008-5472.Can-09-3016

40. Thiolloy S, Edwards JR, Fingleton B, Rifkin DB, Matrisian LM, Lynch CC (2012) An osteoblast-derived proteinase controls tumor cell survival via TGF-beta activation in the bone microenvironment. PLoS ONE 7(1):e29862. doi:10.1371/journal.pone. 0029862

41. Wang D, Christensen K, Chawla K, Xiao G, Krebsbach PH, Franceschi RT (1999) Isolation and characterization of MC3T3E1 preosteoblast subclones with distinct in vitro and in vivo differentiation/mineralization potential. J Bone Miner Res 14(6):893-903. doi:10.1359/jbmr.1999.14.6.893

42. Roudier MP, Morrissey C, True LD, Higano CS, Vessella RL, Ott SM (2008) Histopathological assessment of prostate cancer bone osteoblastic metastases. J Urol 180(3):1154-1160. doi:10.1016/j. juro.2008.04.140
43. Magnusson P, Larsson L, Englund G, Larsson B, Strang P, SelinSjogren L (1998) Differences of bone alkaline phosphatase isoforms in metastatic bone disease and discrepant effects of clodronate on different skeletal sites indicated by the location of pain. Clin Chem 44(8 Pt 1):1621-1628

44. Stein GS, Lian JB, Stein JL, Van Wijnen AJ, Montecino M (1996) Transcriptional control of osteoblast growth and differentiation. Physiol Rev 76(2):593-629

45. Lacey DL, Timms E, Tan HL, Kelley MJ, Dunstan CR, Burgess T, Elliott R, Colombero A, Elliott G, Scully S, Hsu H, Sullivan J, Hawkins N, Davy E, Capparelli C, Eli A, Qian YX, Kaufman S, Sarosi I, Shalhoub V, Senaldi G, Guo J, Delaney J, Boyle WJ (1998) Osteoprotegerin ligand is a cytokine that regulates osteoclast differentiation and activation. Cell 93(2):165-176

46. Honore P, Luger NM, Sabino MAC, Schwei MJ, Rogers SD, Mach DB, O'Keefe PF, Ramnaraine ML, Clohisy DR, Mantyh PW (2000) Osteoprotegerin blocks bone cancer-induced skeletal destruction, skeletal pain and pain-related neurochemical reorganization of the spinal cord. Nat Med 6(5):521-528

47. Pfitzenmaier J, Quinn JE, Odman AM, Zhang J, Keller ET, Vessella RL, Corey E (2003) Characterization of C4-2 prostate cancer bone metastases and their response to castration. $\mathrm{J}$ Bone Miner Res 18(10):1882-1888. doi:10.1359/jbmr.2003.18.10.1882 